Scientific Review - Engineering and Environmental Sciences (2019), 28 (1), 35-48

Sci. Rev. Eng. Env. Sci. (2019), 28 (1)

Przegląd Naukowy - Inżynieria i Kształtowanie Środowiska (2019), 28 (1), 35-48

Prz. Nauk. Inż. Kszt. Środ. (2019), 28 (1)

http://iks.pn.sggw.pl

DOI 10.22630/PNIKS.2019.28.1.4

Ali Zain Al-ABEDEEN Al-OZEER, Mohammed FAKHRALDEEN AHMED

College of Environmental Sciences and Technology, Mosul University

\title{
Groundwater assessment at east side of Mosul City during 2014-2017
}

Key word: groundwater quality (GWQ), attribute risk, weighted assessment, Epidemiological data

\section{Introduction}

The purity of drinking water is essential with no chemical and microbial contaminants like bacteria, viruses and protozoa which cause dangerous diseases like cholera, liver sag, Typhoid fever, dysentery (Cunningham, Daszak \& Rodríguez, 2003). Groundwater quality is largely controlled by the range of human activities in addition to physical and biological properties (Kumar \& Raj, 2018).

Wastewater is the primary source of water pollution in shallow wells which affects the drinking water. Most of harmful microorganisms live in digestive system; sewage, urban and domestic wastewater are widely discharged to groundwater (Tay \& Kortatsi, 2008).

Abawi and Hashem (2001) studied the effect of wastewater leakage to groundwater through the study of 16 wells. The wells' depth ranged between 5 and $14 \mathrm{~m}$ near to the septic tanks distributed at Mosul city. Two wells far away from these septic tanks were used as a control. The results showed an increase of nitrate and phosphate for those near to contaminant sources.

Al-Hayali (2009) studied the groundwater which is situated within Mosul city for drinking and irrigation purposes for 16 wells. The results revealed that most of the wells are not suitable for drinking. The study showed that all samples were classified with high and very high salinity.

Al-Lela, Kharofa, Suheair Akrawi and Shatha (1993) studied using the groundwater at east side of Mosul city for irrigation purpose, and concluded that most of groundwater has high salinity while the other cations $(\mathrm{Ca}, \mathrm{Mg}, \mathrm{Na}$, $\mathrm{K})$ ranged between high to moderate.

Hussen (2002) assessed groundwater quality for 30 wells distributed within Mosul city. The results showed that using these wells was unsuitable for drinking and livestock purposes as they have high salinity. 
This study assesses groundwater quality for 18 shallow wells in the east side of Mosul city for different purposes due to lack of availability of tap water during 2014-2017. Epidemiological analysis shows a risk in using this water based on epidemiological data about diarrhea cases that had been occurred at this period.

This study aims at studying the impacts of wastewater disposal practice on the groundwater quality through studying biological, physical, and chemical properties of groundwater. Also, the study reviews the texture of sub-layers of the studied area by the help of groundwater modelling system - GMS 10.1.
21.5791" E) longitude within municipal boundaries at the east of Mosul city. Figure 1 shows the locations of wells within this area which has $93.40719 \mathrm{~km}^{2}$.

\section{The studied parameters}

Eighteen shallow wells are selected within the studied area to assess their groundwater suitability for different purposes. Many depended parameters are tested for physical, chemical and biological analyses according to international standards (APHA, AWWA, WEF 2005). Parameters pH, Ca, $\mathrm{Mg}, T D S, E C, \mathrm{SO}_{4}$,
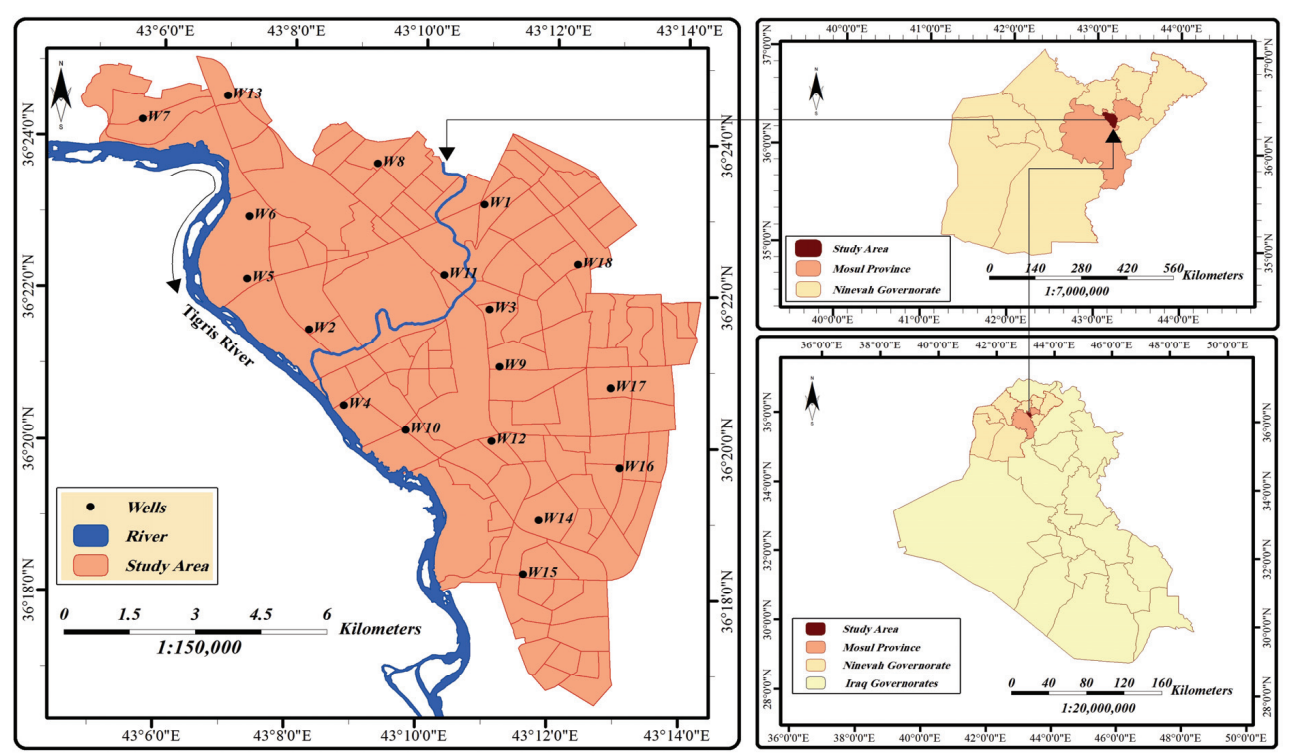

FIGURE 1. The studied area

\section{Materials and methods}

\section{Studied area}

The studied area is located between $\left(36^{\circ} 25^{\prime} 11.0125^{\prime \prime} \mathrm{N}, 36^{\circ} 16^{\prime} 29.2338^{\prime \prime} \mathrm{N}\right)$ latitude and $\left(43^{\circ} 04^{\prime} 43.1214^{\prime \prime} \mathrm{E}, 43^{\circ} 14^{\prime}\right.$
$\mathrm{CL}, \mathrm{NO}_{3}, \mathrm{~B}, \mathrm{~K}, \mathrm{Na}, \mathrm{HCO}_{3}$ and $T C$ are as in Tables 1 and 2. Incubation of positive tubes is used to exam the existence of Escherichia coli. 


\begin{tabular}{|c|c|c|c|c|c|c|c|c|c|c|c|c|c|c|c|c|c|c|}
\hline 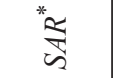 & $\grave{0}$ & $\ddot{o}$ & $\ddot{\circ}$ & $\stackrel{\sim}{-}$ & \begin{tabular}{|l|}
$\infty$ \\
0 \\
0
\end{tabular} & $\begin{array}{l}\infty \\
0 \\
0\end{array}$ & $\begin{array}{l}\infty \\
0\end{array}$ & $\hat{0}$ & $\stackrel{0}{-}$ & $\hat{\circ}$ & $\ddot{\sigma}$ & $\stackrel{\circ}{-}$ & $\stackrel{0}{-}$ & $\stackrel{0}{-}$ & \begin{tabular}{l|l}
$\infty$ \\
$\dot{0}$
\end{tabular} & $\exists$. & $\stackrel{\circ}{-}$ & $\stackrel{\sim}{\longrightarrow}$ \\
\hline 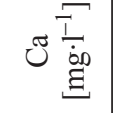 & 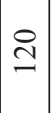 & $\frac{\infty}{\nabla}$ & $\begin{array}{l}0 \\
\infty \\
\sim\end{array}$ & $\begin{array}{l}0 \\
n \\
m\end{array}$ & \begin{tabular}{|l|}
$\infty$ \\
$\infty$ \\
$\infty$
\end{tabular} & $\stackrel{\overbrace{}}{\sim}$ & $\overrightarrow{0}$ & 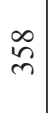 & ¿े & $\mid \begin{array}{c}\infty \\
\infty \\
\infty\end{array}$ & 离 & $\begin{array}{l}\infty \\
\stackrel{0}{0} \\
\sim\end{array}$ & & $\frac{n}{m}$ & ৪) & $\begin{array}{c}\infty \\
\infty \\
m\end{array}$ & $\ddot{\sim}$ & $\frac{O}{m}$ \\
\hline 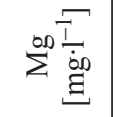 & $\stackrel{2}{2}$ & $\approx$ & ळ & $\hat{0}$ & a & $\tilde{\alpha}$ & $\begin{array}{l}\infty \\
\infty\end{array}$ & 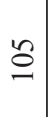 & $\begin{array}{l}+ \\
\overparen{\sigma}\end{array}$ & $\exists$ & $\widehat{\beth}$ & 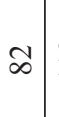 & $\cong$ & 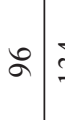 & $\stackrel{\dot{m}}{\sim}$ & $\stackrel{n}{=}$ & $\vec{n}$ & $\stackrel{\infty}{\sim}$ \\
\hline $\bar{z} \frac{\widetilde{I}}{\overrightarrow{\dot{b}_{0}}}$ & 洪 & $\stackrel{\infty}{\sim}$ & 6 & $\hat{a}$ & 6 & in & 8 & 8 & $\nabla$ & $\infty$ & $\infty$ & $\underset{\sim}{ \pm}$ & $\dot{\sigma}$ & $\cong$ & $\approx$ & $\stackrel{\infty}{\circ}$ & $\ddot{0}$ & $\bar{a}$ \\
\hline$\forall \frac{\vec{I}}{\overrightarrow{\dot{b}_{0}}}$ & ชู. & $\stackrel{n}{\sim}$ & $\infty$ & $=$ & $\mid \begin{array}{l}n \\
\infty \\
\infty\end{array}$ & $\cong$ & $r$ & $\begin{array}{l}n \\
n \\
n\end{array}$ & $\begin{array}{c}n \\
\infty\end{array}$ & సे & $\stackrel{\sim}{i}$ & $\stackrel{\circ}{-}$ & $\overbrace{\infty}^{n}$ & $\stackrel{n}{r}$ & $a$ & $\stackrel{\infty}{\sim}$ & $\stackrel{\nabla}{\stackrel{\Delta}{~}}$ & $=$ \\
\hline$\sim \underset{\overrightarrow{\overline{1}}}{\overrightarrow{\dot{b}_{0}}}$ & $\begin{array}{l}\infty \\
\stackrel{\sim}{i}\end{array}$ & $m$ & $\stackrel{\sim}{i}$ & $\vec{m}$ & $\vec{i}$ & \begin{tabular}{|l|}
$\infty$ \\
$\dot{r}$
\end{tabular} & $\stackrel{n}{n}$ & $\vec{m}$ & $\dot{m}$ & $\tilde{m}$ & $\begin{array}{l}\dot{0} \\
\dot{r}\end{array}$ & $\hat{i}$ & 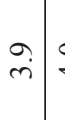 & $\begin{array}{l}\stackrel{+}{+} \\
\end{array}$ & $\vec{m}$ & $\underset{\sim}{\dot{r}} \vec{c}$ & $\vec{m}$ & $\stackrel{\sim}{\sim}$ \\
\hline$\overline{\vec{I}}$ & $\infty$ & 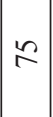 & 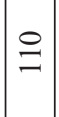 & 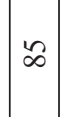 & $\stackrel{?}{=}$ & 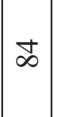 & ஜ & $\infty$ & 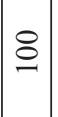 & $\infty$ & $\Xi$ & $\begin{array}{l}\hat{n} \\
\text { iे }\end{array}$ & $\stackrel{+}{\sim}$ & à & ஃ & 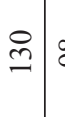 & $\stackrel{\infty}{\circ}$ & సे \\
\hline 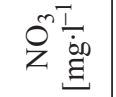 & $\stackrel{+}{m}$ & $\hat{\sim}$ & 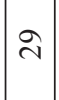 & $\mathscr{F}$ & 吾 & in & F & $\underset{m}{\infty}$ & $\vec{\sim}$ & in & $\approx$ & $\curvearrowright$ & \& & $\approx$ & $\vec{n}$ & $\cong$ & 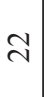 & $\vec{\sigma}$ \\
\hline 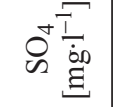 & $\stackrel{ }{\simeq}$ & $\left|\begin{array}{c}\hat{\infty} \\
\text { n }\end{array}\right|$ & $\infty$ & $\left|\begin{array}{l}\tilde{b} \\
⿱ 亠 乂 \\
\end{array}\right|$ & $\overrightarrow{\widetilde{N}}$ & : & $\mid \begin{array}{l}0 \\
n \\
n\end{array}$ & $\stackrel{\overbrace{}}{\curvearrowright}$ & $\frac{\Delta}{m}$ & $\infty$ & $\stackrel{\infty}{\stackrel{\infty}{\sim}}$ & ते & 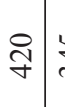 & 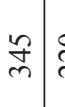 & సి & $\tilde{c}$ & $\underset{\Xi}{ \pm}$ & $\underset{+}{\stackrel{一}{+}}$ \\
\hline 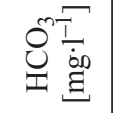 & $\stackrel{8}{8}$ & $\frac{n}{a}$ & $\stackrel{\curvearrowleft}{\infty}$ & 8 & 8 & $\frac{2}{6}$ & 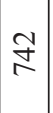 & $\stackrel{0}{0}$ & 옴 & 㐫 & $\stackrel{一}{\circ}$ & $\stackrel{尺}{\circledR}$ & $\frac{0}{\infty}$ & 2 & $\approx$ & $\stackrel{\infty}{\infty}$ & ฉి & $\begin{array}{l}\infty \\
i \\
i\end{array}$ \\
\hline 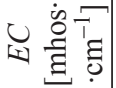 & $\stackrel{\vec{v}}{\mathrm{i}}$ & $\stackrel{n}{m}$ & $\begin{array}{l}0 \\
\text { in }\end{array}$ & $\hat{i}$ & 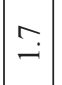 & $\stackrel{\Upsilon}{+}$ & గ̧ & $\stackrel{\sim}{+}$ & $\begin{array}{l}n \\
\sim \\
n\end{array}$ & $\begin{array}{c}\sim \\
\tilde{n}\end{array}$ & $\stackrel{\dot{m}}{.}$ & $\stackrel{\circ}{i}$ & $\tilde{a}^{2}$ & $\stackrel{\oplus}{\dot{m}}=$ & 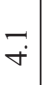 & $\vec{m}$ & $\stackrel{m}{i}$ & $\begin{array}{l}\infty \\
\dot{\sim}\end{array}$ \\
\hline 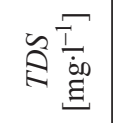 & $\hat{\sigma}$ & $\frac{n}{n}$ & $\begin{array}{l}\vec{f} \\
\infty \\
m\end{array}$ & $\begin{array}{l}\text { 守 } \\
\text { }\end{array}$ & $\left|\begin{array}{c}\tilde{\lambda} \\
\infty \\
-1\end{array}\right|$ & $\left|\begin{array}{l}\hat{n} \\
i n \\
n\end{array}\right|$ & $\begin{array}{l}\hat{b} \\
\infty \\
\nabla\end{array}$ & $\begin{array}{c}\vec{T} \\
\text { 定 }\end{array}$ & $\mid \begin{array}{l}0 \\
\text { 足 } \\
\text { t }\end{array}$ & $\mid \begin{array}{l}\vec{\infty} \\
⿱ 亠 乂 \\
\sim\end{array}$ & $\begin{array}{l}\stackrel{a}{\hat{N}} \\
n\end{array}$ & 今. & \begin{tabular}{l|l}
2 \\
$d$ \\
0
\end{tabular} & 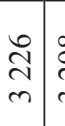 & $\begin{array}{l}\infty \\
\grave{i} \\
m\end{array}$ & \begin{tabular}{l|l}
$m$ \\
$m$
\end{tabular} & $\begin{array}{l}\stackrel{\Xi}{J} \\
\stackrel{v}{v}\end{array}$ & 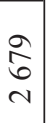 \\
\hline I & $\stackrel{9}{r}$ & $\stackrel{0}{\stackrel{0}{r}}$ & $\stackrel{\infty}{\sim}$ & $\vec{\infty}$ & $\stackrel{9}{\square}$ & $\stackrel{2}{2}$ & $\left|\begin{array}{c}1 \\
\infty \\
\infty\end{array}\right|$ & $\begin{array}{l}0 \\
\therefore \\
\end{array}$ & $\stackrel{\infty}{\stackrel{\infty}{\sim}}$ & $\stackrel{n}{r}$ & $\infty$ & $\begin{array}{c}\text { Ċ } \\
\infty\end{array}$ & $\hat{\sim}$ & $\vec{\infty} \mid r$ & \begin{tabular}{l}
0 \\
\hdashline \\
$r$
\end{tabular} & 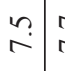 & $\stackrel{\imath}{i}$ & $\stackrel{0}{r}$ \\
\hline$\stackrel{\circ}{z}$ & - & $\sim$ & $m$ & $\nabla$ & in & 0 & $r$ & $\infty$ & $a$ & 이 & $=$ & $\simeq$ & $\cong$ & \pm 4 & $\simeq$ & 0 & I & $\stackrel{\infty}{-}$ \\
\hline
\end{tabular}


TABLE 2. Total Coliform and bacteria type

\begin{tabular}{|c|c|c|}
\hline No & MPN $\cdot 100 \mathrm{ml}^{-1}$ & Bacteria type \\
\hline 1 & 240 & E. coli \\
\hline 2 & 75 & E. coli \\
\hline 3 & 3 & Fecal coliform \\
\hline 4 & 4 & Fecal coliform \\
\hline 5 & 5 & Fecal coliform \\
\hline 6 & 8 & E. coli \\
\hline 7 & 10 & E. coli \\
\hline 8 & 200 & E. coli \\
\hline 9 & 195 & E. coli \\
\hline 10 & 80 & E. coli \\
\hline 11 & 77 & E. coli \\
\hline 12 & 65 & E. coli \\
\hline 13 & 198 & E. coli \\
\hline 14 & 87 & E. coli \\
\hline 15 & 68 & E. coli \\
\hline 16 & 265 & E. coli \\
\hline 17 & 310 & E. coli \\
\hline 18 & 300 & E. coli \\
\hline
\end{tabular}

MPN - most potable number.

\section{Parameters' impacts on groundwater quality}

A brief summary of the parameters' impacts that are considered in assessing groundwater quality for different purposes are shown in Table 3.

\section{Drinking groundwater assessment}

\section{Physical and chemical standards}

Physical and chemical standards of the groundwater quality (GWQ) parameters for drinking purposes are listed in Table 4.

\section{Groundwater modelling system}

Groundwater Modelling System (GMS 10.1) is an extension of GIS which can be used to create a three dimensional profile of underground layers (Anderson \& Woessner, 1992; Kresic, 2007). Input data of cross sections of sub-layers texture of each well is processed. A profile is created to speculate whether an infiltration might occur within the studied area, as in Figure 2.

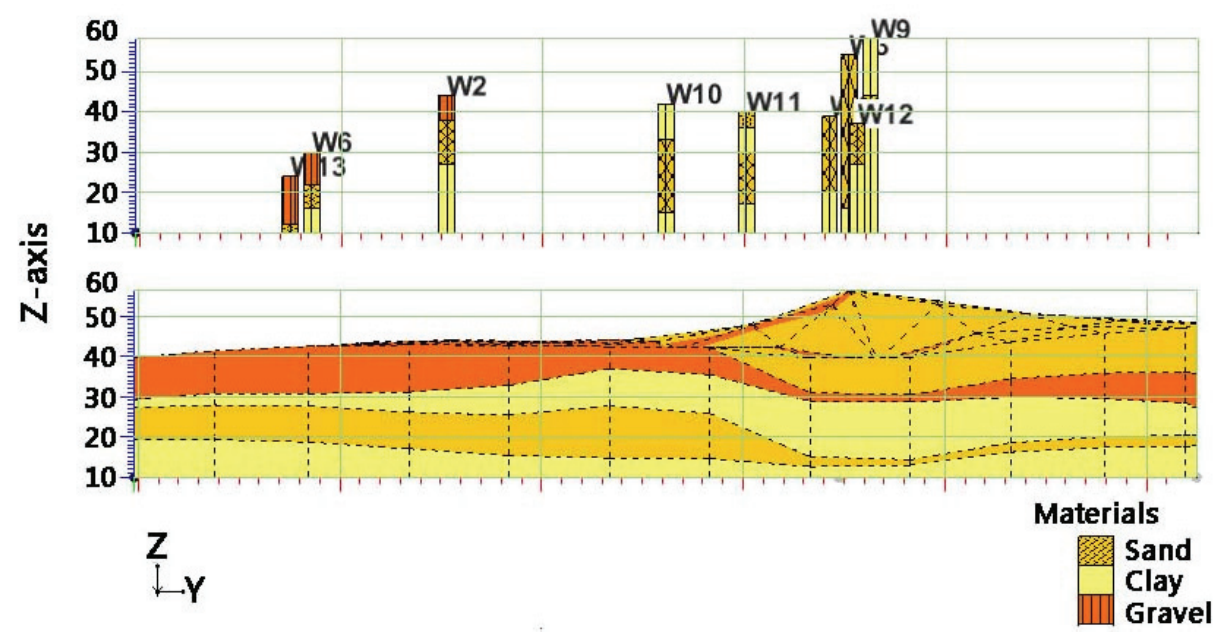

FIGURE 2. Profile of sub-layers 
TABLE 3. The impacts of the selected parameters (EPA, 2001)

\begin{tabular}{|l|l|}
\hline Parameter & Impacts \\
\hline Chloride & $\begin{array}{l}\text { High concentration of } \mathrm{Cl} \text { indicates water pollution by sewage; high } \\
\text { chloride levels may render pure water unsuitable for irrigation }\end{array}$ \\
\hline $\mathrm{pH}$ & $\begin{array}{l}\text { High } \mathrm{pH} \text { causes an increase in Na cations which are toxic in both } \\
\text { soil and plants; low } \mathrm{pH} \text { : causes an increase of (Al) and (Mn) } \\
\text { cations which are toxic to the crops }\end{array}$ \\
\hline Sulfate & High concentration causes unlikable odor of hydrogen sulfide \\
\hline Total dissolved solids $-T D S$ & The high concentration of TDS increases the density of water \\
\hline Sodium & $\begin{array}{l}\text { High concentrations of sodium can cause cardiovascular diseases, } \\
\text { and is toxic to plants }\end{array}$ \\
\hline Nitrate & $\begin{array}{l}\text { High concentrations are hazardous to infants as they stimulate the } \\
\text { "blue baby" disease }\end{array}$ \\
\hline Total hardness $-T H$ & High concentrations can cause heart cardiovascular disease \\
\hline Sodium adsorption ratio $-S A R$ & High value is unsuitable for irrigation \\
\hline Hydro carbonate & $\begin{array}{l}\text { The presence of this anion in groundwater indicates that there is high } \\
\text { concentration of soluble CO }{ }_{2} \text { in water and less of dissolved } \mathrm{O}_{2}\end{array}$ \\
\hline Total coliform $-T C$ & Indicates the presence of wastewater in the analyzed water samples \\
\hline Boron & $\begin{array}{l}\text { It is considered dangerous to crops in irrigation at } 1-2 \text { mg }{ }^{-1} \\
\text { concentration }\end{array}$ \\
\hline Calcium and Magnesium & High concentration is related to heart diseases \\
\hline Electrical conductivity $-E C$ & Indicator of hardness and alkalinity values \\
\hline
\end{tabular}

TABLE 4. Standards for drinking groundwater quality - DGWQ (EPA, 2001)

\begin{tabular}{|c|c|c|}
\hline Parameter & Maximum permissible concentration & Unit \\
\hline Calcium $\left(\mathrm{Ca}^{2+}\right)$ & 75 & $\mathrm{mg} \cdot 1^{-1}$ \\
\hline Magnesium $\left(\mathrm{Mg}^{2+}\right)$ & 100 & $\mathrm{mg} \cdot 1^{-1}$ \\
\hline Sodium $\left(\mathrm{Na}^{+}\right)$ & 200 & $\mathrm{mg} \cdot 1^{-1}$ \\
\hline Potassium $\left(\mathrm{K}^{+}\right)$ & 12 & $\mathrm{mg} \cdot 1^{-1}$ \\
\hline Bicarbonate $\left(\mathrm{HCO}_{3}^{-}\right)$ & 400 & $\mathrm{mg} \cdot 1^{-1}$ \\
\hline Sulphate $\left(\mathrm{SO}_{4}{ }^{-}\right)$ & 250 & $\mathrm{mg} \cdot 1^{-1}$ \\
\hline Chloride $\left(\mathrm{Cl}^{-}\right)$ & 250 & $\mathrm{mg} \cdot 1^{-1}$ \\
\hline Nitrate $\left(\mathrm{NO}_{3}{ }^{-1}\right.$ & 10 & - \\
\hline pH & $6.5-8.5$ & $\mathrm{mg} \cdot 1^{-1} \mathrm{as} \mathrm{CaCO}$ \\
\hline Total hardness $-T H$ & 300 & $\mathrm{mg} \cdot 1^{-1}$ \\
\hline Total dissolved solis $-T D S$ & 500 & $\mathrm{MPN} \cdot 100 \mathrm{ml}$ \\
\hline Total coliform $-T C$ & 0 & \\
\hline
\end{tabular}




\section{Relative, odd and attributed risk}

Epidemiological data of the diarrhea cases that had been occurred at the period 2014-2017, are shown in Table 5. tive, attribute, and odd risk from the used matrix:

relative risk $=a /(a+b) / c /(c+d)$.

TABLE 5. Number of diarrhea cases during 2014-2017 (Al-Salam Mosul Hospital, 2018)

\begin{tabular}{|c|c|c|c|c|}
\hline No of month & 2014 & 2015 & 2016 & 2017 \\
\hline 1 & 33 & 163 & 68 & 21 \\
\hline 2 & 48 & 96 & 94 & 59 \\
\hline 3 & 61 & 124 & 113 & 89 \\
\hline 4 & 89 & 120 & 126 & 65 \\
\hline 5 & 111 & 67 & 135 & 83 \\
\hline 6 & nil & 136 & 224 & 89 \\
\hline 7 & nil & 121 & 332 & 155 \\
\hline 8 & 106 & 183 & 410 & 135 \\
\hline 9 & 112 & 127 & 253 & 177 \\
\hline 10 & 67 & 58 & nil & 123 \\
\hline 11 & 53 & 45 & nil & 110 \\
\hline 12 & 39 & 65 & nil & 21 \\
\hline Total & 719 & 1305 & 1755 & 1127 \\
\hline
\end{tabular}

Preliminary data analysis involves setting up a simple matrix with two rows and two columns, the columns divide the subjects according to those who were not diseased, and those who weren't diseased. The rows divide the subjects according to those who were exposed, and those who were not exposed (Masters \& Ela, 1998). The symbols of values (a, b, c and d) used in $2 \times 2$ matrix are extracted from Table 5 and tabulated in Table 6.

In the following a brief of the equations that considered to extract the rela-

TABLE 6. Preliminary data analysis

\begin{tabular}{|l|l|l|}
\hline Subjects & Diseased & Not Diseased \\
\hline Exposed & $a=41 \%$ & $b=59 \%$ \\
\hline Not exposed & $c=10.6 \%$ & $d=89.4 \%$ \\
\hline
\end{tabular}

Explanations in the text.
The relative risk must be equal to 1 . If the relative risk, above 1.0, there is a direct exposure-risk proportion:

odd risk $=a \cdot b / c \cdot d$.

The odds ratio suggests a exposure-risk relationship.

attributed risk $=a /(a+b)-c /(c+d)$.

An attributed risk of 0 suggests no exposure-risk relationship.

\section{Irrigation groundwater} Assessment

\section{Irrigation groundwater standards}

Parameters under study which are used for irrigation and their depended standards are listed in Table 7. 
TABLE 7. Standards of parameters used for irrigation (EPA, 2001)

\begin{tabular}{|c|c|c|}
\hline Parameter & Unit & Standards \\
\hline TDS & $\mathrm{mg} \cdot \mathrm{l}^{-1}$ & 1750 \\
\hline $\mathrm{EC}$ & $\mathrm{mhos} \cdot \mathrm{cm}^{-1}$ & 2.7 \\
\hline $\mathrm{Na}$ & - & $6.5-8.5$ \\
\hline $\mathrm{Cl}$ & $\mathrm{mg} \cdot \mathrm{l}^{-1}$ & 200 \\
\hline $\mathrm{B}$ & $\mathrm{mg} \cdot \mathrm{l}^{-1}$ & 250 \\
\hline $\begin{array}{c}\text { Coli form for } \\
\text { food plants }\end{array}$ & $\mathrm{MPN} \cdot 100 \mathrm{ml}^{-1}$ & $23 \mathrm{cell} \cdot 100 \mathrm{ml}^{-1}$ \\
\hline $\begin{array}{c}\text { Coli form } \\
\text { for non-food } \\
\text { plants }\end{array}$ & $\mathrm{MPN} \cdot 100 \mathrm{ml}^{-1}$ & 240 cell $\cdot 100 \mathrm{ml}^{-1}$ \\
\hline
\end{tabular}

\section{Problem associated with using groundwater quality}

There are many problems associated with using IGW purpose. They are, salinity, specific ion toxicity, and microbial effects (EPA, 2004).

There is an inverse proportion in saline irrigation water-root cells relationship due to osmotic pressure gradient which results in reduction of plant growth. Tables 1 and 8 show a severe impact of salinity represented by $E C$ and $T D S$.

TABLE 8. Irrigation salinity impacts (EPA, 2004)

\begin{tabular}{|c|c|c|c|c|}
\hline \multirow{2}{*}{$\begin{array}{c}\text { Para- } \\
\text { meter }\end{array}$} & Unit & \multicolumn{3}{|c|}{ Salinity impacts range } \\
\cline { 3 - 5 } & none & $\begin{array}{c}\text { slight to } \\
\text { moderate }\end{array}$ & severe \\
\hline EC & $\mathrm{mhos}^{\prime} \mathrm{cm}^{-1}$ & $<0.7$ & $0.7-3$ & $>0.3$ \\
\hline TDS & $\mathrm{mg} \cdot \mathrm{l}^{-1}$ & $<450$ & $450-2000$ & $>2000$ \\
\hline
\end{tabular}

Three specific ions which must be considered in irrigation, they are boron (B), sodium $(\mathrm{Na})$, and chloride $(\mathrm{Cl})$. The source of boron is usually comes from household detergents or discharges from industrial plants. The quantities of chloride ions increases as a result of domestic usage. Tables 1 and 9 show that boron has a severe impact while chloride has slight to moderate impact in some wells while the other wells show no impact. Finally, sodium impact expressed as $S A R$ which has no effect due to high existence of dictations causing low sodium adsorption ratio $S A R$.

TABLE 9. Irrigation specific ion toxicity impacts

\begin{tabular}{|c|c|c|c|c|}
\hline \multirow{2}{*}{$\begin{array}{c}\text { Para- } \\
\text { meter }\end{array}$} & \multirow{2}{*}{ Unit } & \multicolumn{3}{|c|}{ Specific ion toxicity range } \\
\cline { 3 - 5 } & & none & $\begin{array}{c}\text { slight to } \\
\text { moderate }\end{array}$ & severe \\
\hline $\mathrm{Na}$ & - & $S A R<3.0$ & $S A R(3.0-9.0)$ & $S A R>9.0$ \\
\hline $\mathrm{Cl}$ & $\mathrm{mg} \cdot \mathrm{l}^{-1}$ & $\mathrm{Cl}<140$ & $\mathrm{Cl}(140-350)$ & $\mathrm{Cl}>350$ \\
\hline $\mathrm{B}$ & $\mathrm{mg} \cdot \mathrm{l}^{-1}$ & $\mathrm{~B}<0.7$ & $\mathrm{~B}(0.7-3.0)$ & $\mathrm{B}>3.0$ \\
\hline
\end{tabular}

There is an inverse proportion between total coliform and groundwater quality, especially on crops. The maximum number of total coliform is 23 and 240 cell per $100 \mathrm{ml}$ for food and non-food crops respectively (EPA, 2004). Most of wells show huge impact of microbial on food crops, as in Table 2.

\section{Methods used in groundwater classification}

Three methods are used to classify the groundwater for irrigation purpose (US-SL, 1954). US-SL classifies water quality for irrigation purpose according to the concentration of salinity into four classless ranking from little salt (100-250 $\left.\mu \mathrm{hos} \cdot \mathrm{cm}^{-1}\right)$ which is suitable for most of plants to very high salt which is suitable for plants with high resistance to salinity with both good drainage and high permeability soil $(2,250-5,000$ $\mu$ hos $\cdot \mathrm{cm}^{-1}$ ). 
Richard (1954) classified water quality for irrigation based on $S A R$ and $E C$ and ranked water quality into 16 classes from excellent (low sodium and low salinity) to poor (very high sodium and very high salinity).

Todd, Leaden and Trosise (1990) classified water quality for irrigation which includes five classes of water quality from excellent to unsuitable based on percentage of sodium ion and $E C$. A comparison among the three classifications in illustrated in Table 10.

TABLE 10. A comparison among three groundwater classifications

\begin{tabular}{|c|c|c|c|}
\hline No & $\begin{array}{c}\text { (Richard, } \\
1954)\end{array}$ & $\begin{array}{c}\text { (US-SL, } \\
1954)\end{array}$ & $\begin{array}{l}\text { (Todd, Leaden } \\
\text { \&Trosise, 1990) }\end{array}$ \\
\hline 1 & very poor & \# & suitable \\
\hline 2 & very poor & $\#$ & $\begin{array}{l}\text { doubtful to } \\
\text { unsuitable }\end{array}$ \\
\hline 3 & very poor & \# & unsuitable \\
\hline 4 & very poor & $\#$ & unsuitable \\
\hline 5 & admissible & $\#$ & $\begin{array}{l}\text { doubtful to } \\
\text { unsuitable }\end{array}$ \\
\hline 6 & very poor & \# & good to permissible \\
\hline 7 & very poor & \# & unsuitable \\
\hline 8 & very poor & $\#$ & unsuitable \\
\hline 9 & very poor & $\#$ & unsuitable \\
\hline 10 & very poor & $\#$ & unsuitable \\
\hline 11 & very poor & $\#$ & unsuitable \\
\hline 12 & admissible & \# & unsuitable \\
\hline 13 & very poor & $\#$ & $\begin{array}{l}\text { doubtful to } \\
\text { unsuitable }\end{array}$ \\
\hline 14 & very poor & \# & unsuitable \\
\hline 15 & very poor & $\#$ & unsuitable \\
\hline 16 & very poor & $\#$ & unsuitable \\
\hline 17 & very poor & \# & unsuitable \\
\hline 18 & very poor & \# & $\begin{array}{l}\text { doubtful to } \\
\text { unsuitable }\end{array}$ \\
\hline
\end{tabular}

\# Suitable for plants with high resistance to saline water if there is good drainage system for soils with high permeability.

\section{Groundwater standards for livestock}

Higher levels of suspended solids and salinity may be tolerated by certain livestock showing a flexibility with higher ranges than human. Standards for livestock groundwater are tabulated in Table 11.

TABLE 11. Livestock groundwater suitability standards (WHO, 2003)

\begin{tabular}{|c|c|c|}
\hline Parameter & Unit & Standards \\
\hline $\mathrm{TDS}$ & $\mathrm{mg} \cdot \mathrm{l}^{-1}$ & 10000 \\
\hline $\mathrm{SO}_{4}$ & $\mathrm{mg} \cdot l^{-1}$ & 1000 \\
\hline $\mathrm{pH}$ & - & $6.5-8.5$ \\
\hline $\mathrm{NO}_{3}$ & $\mathrm{mg} \cdot l^{-1}$ & 440 \\
\hline $\mathrm{EC}$ & $\mathrm{mhos} \cdot \mathrm{cm}^{-1}$ & 12.5 \\
\hline $\begin{array}{c}\text { Total coliform } \\
-T C\end{array}$ & cell $\cdot 100 \mathrm{ml}^{-1}$ & 100 cell $\cdot 100 \mathrm{ml}^{-1}$ \\
\hline
\end{tabular}

\section{Groundwater quality index (weighted assessment)}

Groundwater quality index $(G W Q I)$ gives the weight of the groundwater for each well. The used procedure for extracting indices is used by many researchers such as Abdul Hameed, Alobaidy, Mauloood and Kadhem (2010), and Reza and Singh (2010). The procedure is summarized as follows: Each parameter is given a weight according to its importance where number one is the least important and number five is the highest one. The relative weight (wi) is calculated by dividing the estimated importance of each parameter by the summation of total weights of parameters. The quality rating scale ( $q i)$ is computed by using the following equation: $q i=(\mathrm{Ci} / \mathrm{Si}) \cdot 100$, where $C i$ represents the concentration of 
TABLE 12. Groundwater quality index - GWQI

\begin{tabular}{|c|c|c|c|c|c|c|}
\hline \multirow{2}{*}{ No } & \multicolumn{2}{|c}{$D G W Q I$} & \multicolumn{2}{c|}{$I G W Q I$} & \multicolumn{2}{c|}{ LGWQI } \\
\cline { 2 - 7 } & drinking & suitability & irrigation & suitability & livestock & suitability \\
\hline 1 & 4262 & unfit & 194 & unfit & 63 & poor \\
\hline 2 & 1512 & unfit & 96 & very poor & 45 & good \\
\hline 3 & 268 & unfit & 50 & good & 33 & good \\
\hline 4 & 273 & unfit & 49 & good & 34 & good \\
\hline 5 & 264 & unfit & 42 & good & 26 & good \\
\hline 6 & 364 & unfit & 25 & excellent & 35 & good \\
\hline 7 & 488 & unfit & 67 & poor & 45 & good \\
\hline 8 & 3667 & unfit & 177 & unfit & 66 & poor \\
\hline 9 & 370 & unfit & 175 & unfit & 69 & poor \\
\hline 10 & 1577 & unfit & 97 & very poor & 41 & good \\
\hline 11 & 1544 & unfit & 102 & unfit & 45 & good \\
\hline 12 & 1270 & unfit & 79 & very poor & 39 & good \\
\hline 13 & 3775 & unfit & 564 & unfit & 82 & very poor \\
\hline 14 & 1706 & unfit & 113 & unfit & 48 & good \\
\hline 15 & 1395 & unfit & 93 & very poor & 46 & good \\
\hline 16 & 4781 & unfit & 221 & unfit & 76 & very poor \\
\hline 17 & 5486 & unfit & 240 & unfit & 78 & very poor \\
\hline 18 & 5371 & unfit & 241 & unfit & 85 & very poor \\
\hline
\end{tabular}

0-25 excellent, 25-50 good, 51-75 poor, 76-100 very poor $>100$ units. DGWQI - drinking groundwater quality index; $I G W Q I$ - irrigation groundwater quality index; $L G W Q I$ - livestock groundwater quality index

the given parameter, $S i$ represents international standards. Then, the sub index Sli of a given parameter computed by multiplying the relative weight by the quality rating using the equation: $S I i=$ $=w i \cdot q i$. Then, GWQI is computed by summation of sub-indices as in the equation: $G W Q I=\sum S I i$. This index has four ranges (excellent to unfit). The results appear in Table 12.

\section{Representation of groundwater quality index by GIS}

Arc GIS 10.2 with its geostatical analyst is used to represent GWQIs data from Table 12 for all purposes using Kernal interpolation tool, as in Figures 14a, $\mathrm{b}$ and $14 \mathrm{c}$. Overlay-union tool is used to create spatial fitting for $I G W Q I$ and $L G W Q I$ except $D G W Q I$ which is unfit. 


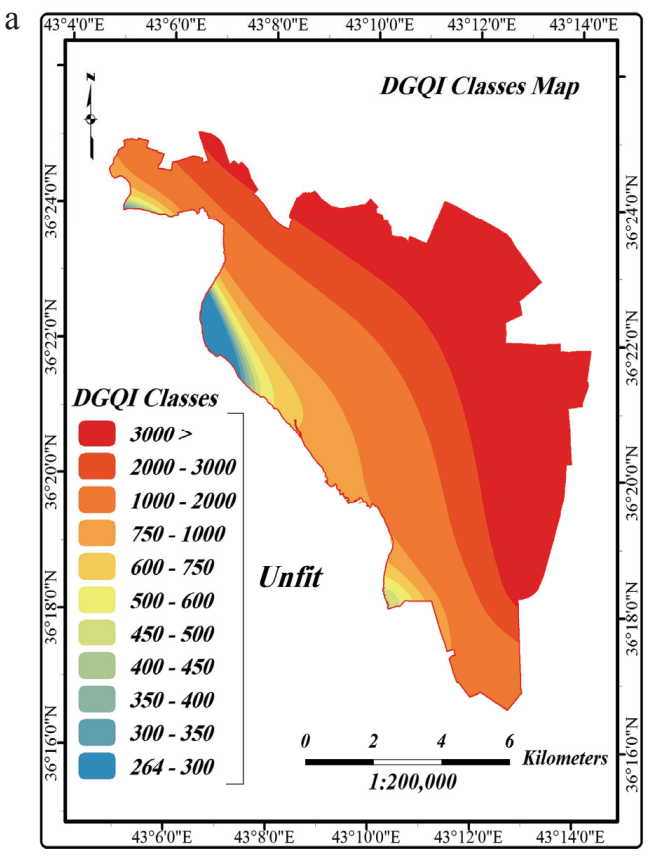

FIGURE 4a. Drinking groundwater suitability areas based on drinking index

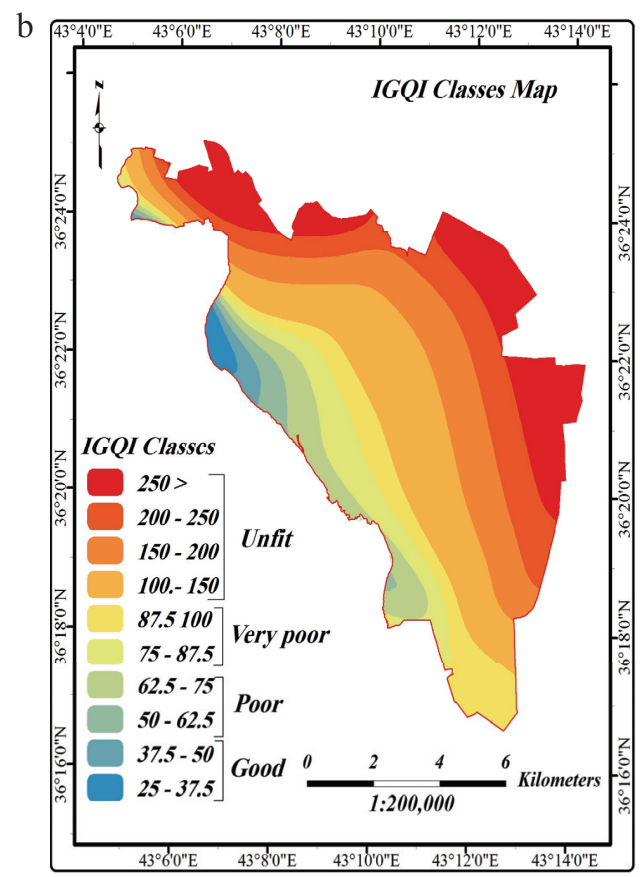

FIGURE 4b. Irrigation groundwater suitability areas

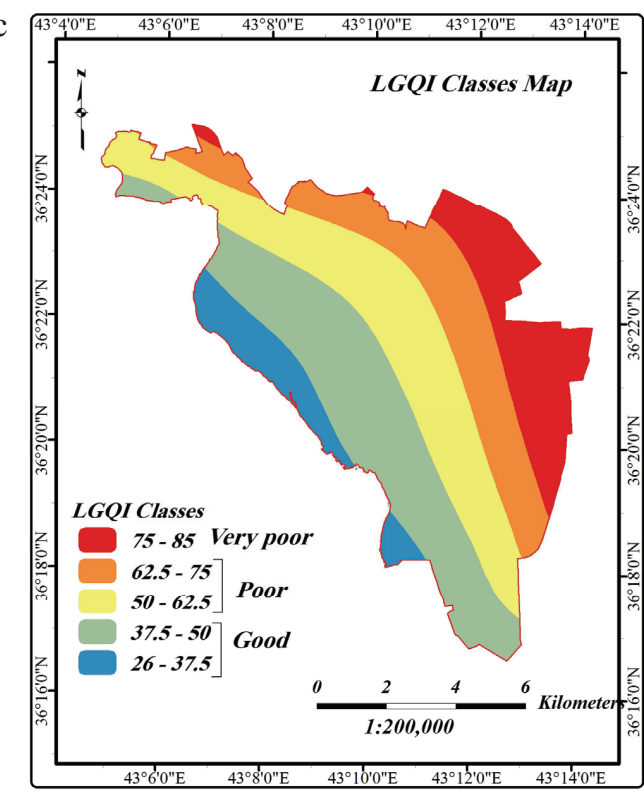

FIGURE 4c. Live stock groundwater suitability areas

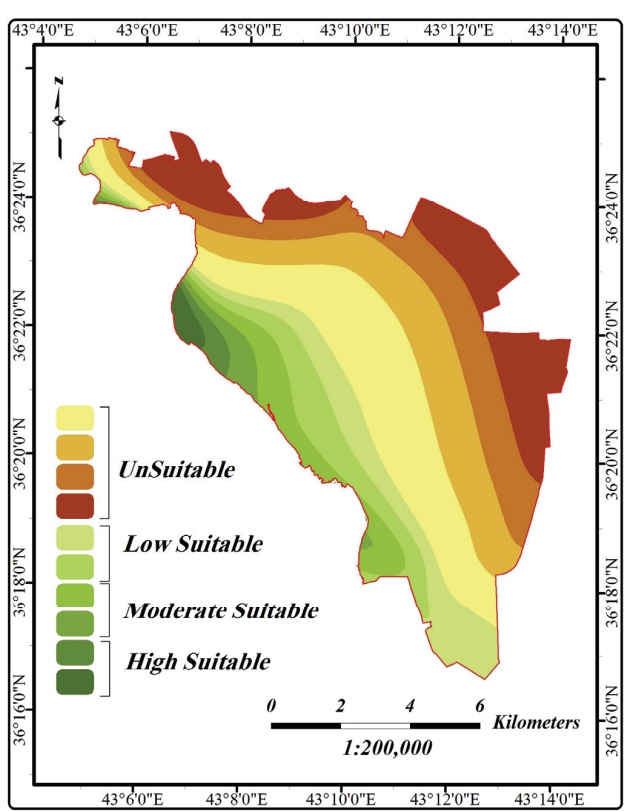

FIGURE 5. Suitability classes areas or irrigation and livestock 
Suitable areas for Figures $4 b$, and c are overlaid with select by attribute tool. The output areas rank from high suitable to unsuitable. As in Figure 15, the suitability classes increases in areas nearby the river due to dilution of raw water which decrease the impacts of the polluted groundwater.
The process of ranking assessment of parameters has been done according to their degree of effect and marked by a number of increasing stars (from low to very high effect), or different shades. These stars and shades can point out the most effective parameter that decrease GWQ. Groundwater ranking assessment is tabulated in Table 13.

TABLE 13. Groundwater ranking assessment

\begin{tabular}{|c|c|c|c|c|c|c|c|c|c|c|c|c|c|c|c|}
\hline \multicolumn{9}{|c|}{ Drinking ranking assessment } & \multicolumn{4}{|c|}{$\begin{array}{l}\text { Irrigation ranking } \\
\text { assessment }\end{array}$} & \multicolumn{3}{|c|}{$\begin{array}{c}\text { Livestock ranking } \\
\text { assessment }\end{array}$} \\
\hline \multirow[b]{2}{*}{ No } & \multirow[b]{2}{*}{$T C_{1}$} & \multirow[b]{2}{*}{$\mathrm{NO}_{3}$} & \multirow[b]{2}{*}{$T H$} & \multirow[b]{2}{*}{$\mathrm{Mg}$} & \multirow[b]{2}{*}{$\mathrm{Ca}$} & \multirow[b]{2}{*}{$\mathrm{HCO}_{3}$} & \multirow[b]{2}{*}{$\mathrm{SO}_{4}$} & \multirow[b]{2}{*}{$T D S$} & \multirow[b]{2}{*}{ Sal. } & \multicolumn{3}{|c|}{ ions toxicity } & \multirow[b]{2}{*}{$T C_{2}$} & \multirow{2}{*}{$\begin{array}{l}T D S, \\
E C, \\
\mathrm{SO}^{4}, \\
\mathrm{NO}^{3}\end{array}$} & \multirow[b]{2}{*}{$\mathrm{TC}_{3}$} \\
\hline & & & & & & & & & & $\mathrm{Cl}$ & $\mathrm{Na}$ & $\mathrm{B}$ & & & \\
\hline 1 & $* * * *$ & $* * *$ & $* *$ & $\mathrm{~N}$ & $* *$ & $* *$ & $\mathrm{~N}$ & $* * *$ & $* * *$ & $*$ & $\mathrm{~N}$ & $* *$ & $* * *$ & $\mathrm{~N}$ & $* *$ \\
\hline 2 & $* * * *$ & $* *$ & $* * *$ & $\mathrm{~N}$ & $* * *$ & $* * *$ & $* *$ & $* * * *$ & $* * * *$ & $*$ & $\mathrm{~N}$ & $* * *$ & $* * *$ & $\mathrm{~N}$ & $\mathrm{~N}$ \\
\hline 3 & $* * *$ & $* *$ & $* * *$ & $\mathrm{~N}$ & $* * *$ & $* * *$ & $* *$ & $* * * *$ & $* * * *$ & $*$ & $\mathrm{~N}$ & $* *$ & $\mathrm{~N}$ & $\mathrm{~N}$ & $\mathrm{~N}$ \\
\hline 4 & $* * *$ & $* * * *$ & $* * *$ & $*$ & $* * *$ & $* * *$ & $* *$ & $* * * *$ & $* * *$ & $*$ & $\mathrm{~N}$ & $* * *$ & $\mathrm{~N}$ & $\mathrm{~N}$ & $\mathrm{~N}$ \\
\hline 5 & $* * *$ & $* * *$ & $* * *$ & $\mathrm{~N}$ & $* * * *$ & $* * *$ & $\mathrm{~N}$ & $* * * *$ & $* * *$ & $*$ & $\mathrm{~N}$ & $* *$ & $\mathrm{~N}$ & $\mathrm{~N}$ & $\mathrm{~N}$ \\
\hline 6 & $* * * *$ & $* * * *$ & $* *$ & $\mathrm{~N}$ & $* * *$ & $* * *$ & $* *$ & $* * * *$ & $* * * *$ & $*$ & $\mathrm{~N}$ & $* * *$ & $* * *$ & $\mathrm{~N}$ & $\mathrm{~N}$ \\
\hline 7 & $* * * *$ & $* * * *$ & $* * * *$ & $* *$ & $* * * *$ & $* * *$ & $* * *$ & $* * * *$ & $* * * *$ & $*$ & $\mathrm{~N}$ & $* * *$ & $* * *$ & $\mathrm{~N}$ & $\mathrm{~N}$ \\
\hline 8 & $* * * *$ & $* * *$ & $* * *$ & $* *$ & $* * *$ & $* * * *$ & $\mathrm{~N}$ & $* * * *$ & $* * * *$ & $*$ & $\mathrm{~N}$ & $* * *$ & $* * *$ & $\mathrm{~N}$ & $\mathrm{~N}$ \\
\hline 9 & $* * * *$ & $*$ & $* * *$ & $* * * *$ & $* * *$ & $* * *$ & $* *$ & $* * * *$ & $* * * *$ & $*$ & $\mathrm{~N}$ & $* * *$ & $* * *$ & $\mathrm{~N}$ & $\mathrm{~N}$ \\
\hline 10 & $* * * *$ & $* * *$ & $* * * *$ & $* *$ & $* * * *$ & $* * *$ & $\mathrm{~N}$ & $* * * *$ & $* * * *$ & $*$ & $\mathrm{~N}$ & $* * *$ & $* * *$ & $\mathrm{~N}$ & $*$ \\
\hline 11 & $* * * *$ & $* * *$ & $* * *$ & $* *$ & $* * * *$ & $* * *$ & $* *$ & $* * * *$ & $* * * *$ & $*$ & $\mathrm{~N}$ & $* * *$ & $* * *$ & $\mathrm{~N}$ & $* *$ \\
\hline 12 & $* * * *$ & $*$ & $* * *$ & $\mathrm{~N}$ & $* * *$ & $* * *$ & $* *$ & $* * * *$ & $* * *$ & $*$ & $\mathrm{~N}$ & $* *$ & $* * *$ & $\mathrm{~N}$ & $*$ \\
\hline 13 & $* * * *$ & $* * * *$ & $* * *$ & $* *$ & $* * * *$ & $* * *$ & $* *$ & $* * * *$ & $* * * *$ & $*$ & $\mathrm{~N}$ & $* * *$ & $* * *$ & $\mathrm{~N}$ & $* *$ \\
\hline 14 & $* * * *$ & $* *$ & $* * *$ & $\mathrm{~N}$ & $* * * *$ & $* * *$ & $* *$ & $* * * *$ & $* * * *$ & $*$ & $\mathrm{~N}$ & $* * *$ & $* * *$ & $\mathrm{~N}$ & $\mathrm{~N}$ \\
\hline 15 & $* * * *$ & $* * * *$ & $* * *$ & $* *$ & $* * * *$ & $* * *$ & $\mathrm{~N}$ & $* * * *$ & $* * * *$ & $*$ & $\mathrm{~N}$ & $* * *$ & $* * *$ & $\mathrm{~N}$ & $* *$ \\
\hline 16 & $* * * *$ & $*$ & $* * *$ & $* *$ & $* * * *$ & $* * *$ & $* *$ & $* * * *$ & $* * * *$ & $*$ & $\mathrm{~N}$ & $* * *$ & $* * *$ & $\mathrm{~N}$ & $* * *$ \\
\hline 17 & $* * * *$ & $* *$ & $* *$ & $\mathrm{~N}$ & $* * *$ & $* * *$ & $\mathrm{~N}$ & $* * * *$ & $* * *$ & $*$ & $\mathrm{~N}$ & $* * *$ & $* * *$ & $\mathrm{~N}$ & $* *$ \\
\hline 18 & $* * * *$ & $* * * *$ & $* * *$ & $\mathrm{~N}$ & $* * * *$ & $* *$ & $* * *$ & $* * * *$ & $* * *$ & $*$ & $\mathrm{~N}$ & $* * *$ & $* * *$ & $\mathrm{~N}$ & $* * *$ \\
\hline
\end{tabular}

$\mathrm{N}$ - no effect (no shade); ${ }^{*}$ light effect (light shade), ${ }^{* *}$ moderate effect (moderate shade), $* * *$ high effect (high shade), ****extreme effect (extreme shade); $T H$ - total hardness, EC - electrical conductivity, $T C$ - total coliform, Sal. - sensitive crops salinity; All parameter units in $\mathrm{mg} \cdot \mathrm{l}^{-1}$ except $T H$ - in $\mathrm{mg} \cdot \mathrm{l}^{-1}$ as $\mathrm{CaCO}_{3}, E C$ in mhos $\mathrm{cm}^{-1}, T C$ in MPN $\cdot 100 \mathrm{ml}^{-1} ; T C_{1}$ - total coliform ranking in drinking water, $T C_{2}$ - total coliform ranking for irrigation (for food crops), $T C_{3}$ - total coliform ranking for livestock. 


\section{Results and discussion}

Most of wells are classified as unfit for drinking as in Table 11 due to high permissible infiltration of waste and grey water (upper layer mostly course texture), as in Figure 4. The main parameters affecting $D G W Q$ are: $T C, T D S, \mathrm{NO}_{3}, \mathrm{HCO}_{3}$ and $\mathrm{SO}_{4}$ in sequence as in Table 13. There is a range of values for unsuitability representing unfit for using the studied ground water for drinking purpose, as in Figure 4a. The epidemiological data show that relative risk is 3.8 , and odd risk is 5.8 , and attribute risk is 0.34 .

A number of wells are unfit for irrigation except those nearby the river 3 , 4, 5 and 6 which they are unsuitable for crops with sensitivity for high salinity as in Figure 4b. The main parameters affecting $I G W Q$ are salinity, $T C$, Boron (B) and Chloride in sequence as in Table 13.

For livestock purpose, the majority of wells are classified as suitable except those far away from the river (wells 16, 17 and 18, as in Figure 4b). The main parameter affecting $L G W Q$ are the presence of in their watering, as in Table 13.

Final map in Figure 5 shows classes of areas having combined suitability between irrigation and livestock watering ranked from high suitability nearby the river to the unsuitable for those far away.

Epidemiological data of relative and odd risk of diarrhea analysis indicate exposure-disease relationship due to the fact that both of their values are higher than one. The result of the attributed risk of those who were exposed is higher than non exposed by three folds. The IGWQ is classified as very poor and unsuitable according to Richard (1954) and Todd, Leaden and Trosise (1990), while $I G W Q$ is classified according to US-SL (1954) as suitable for plants with high resistance to saline water if there is good drainage system for soils with high permeability.

\section{Conclusions}

The importance of this study comes from developing GIS model with GMS extension to draw geological layers of the studied area. Also, it conducts an analysis of spatial and epidemiological data to assess the degree of hazard of the water samples.

The groundwater which was used during 2014-2017 is unsuitable for drinking with a attributed huge risk. Most of the diarrhea cases especially in summer of 2016 indicates the polluted of water used for drinking purposes represented by the existence of $T C$ as the main cause with high concentrations of salinity and nitrate. One of the main causes of groundwater pollution is the course texture of soil layers with high permissible infiltration of wastewater and grey water.

The studied samples are suitable only for plants having high resistance to saline water, if and only if, there is good drainage system for soils having high permeability. Most of the wells are suitable for live stock purpose, except (wells 16 and 17) due to the existence of high coliform values.

The study data analysis indicates that more far the well's location from the river relates to less suitability. It is vital to say that, although the studied water was used for a limited duration only during war processes but its risk was very high represented by the increase of pathological cases. 


\section{References}

Abawi, S.A. \& Hashem, A. (2001). Studying the Effect of Septic Tanks Municipal Waste and the Leakage of Wastewater on the Groundwater Quality at Mosul city, Al-Rafedain Engineering Journal, 9(2).

Abdul Hameed, M., Alobaidy, J., Mauloood B. \& Kadhem, A. (2010). Evaluating Raw and Treated water Quality of Tigris River within Baghdad by Index Analysis, Journal of Water Resource and Protection, 2, 629-635.

Al-Hayali, A.K. (2010). Studying the Groundwater Quality in Mosul city and Showing the Range of their Suitability for Drinking and Irrigation. Journal of Education and Science, 23(3), 10-20.

Al-Lela, M.A., Kharofa, Suheair N, Akrawi \& Shatha, M. (1993). The Possibility of using the Groundwater for Agriculture and Irrigation Purpose at Mosul city. Engineering Scientific Journal, 11, 25-38.

Al-Salam Mosul Hospital (2018). Data of diarrhea cases during 2014-2017. Mosul: Planning Department.

Anderson, M.P. \& Woessner, W.W. (1992). Groundwater Modeling Simulation of Flow and advective transport. San Diego: Academic Press.

APHA, AWWA, WEF (2005). Standard Methods for The Examination of Water and $21^{s t}$ Edn. Wastewaters. Washington DC: American Public Health Association

Cunningham, A.A., Daszak, P. \& Rodríguez, J.P. (2003) Pathogen pollution: defining a parasitological threat to biodiversity conservation. Journal of Parasitology, 89, 78-S83.

EPA (2004). Guidelines for Water Reuse, EPA/625/R-04/108,U.S. Washington, DC: Environmental Protection Agency and U.S. Agency for International Development.

Hussen M. (2002). The Problems of Groundwater at Mosul city, its Reasons and the Possible Solutions (MSc thesis). Engineering Collage, Mosul University, Mosul.

Engineering Collage, Mosul University, mosul.

Keresic, N. (2007). Hydrogeology and groundwater Modeling. 2nd edn. Boca Raton: CRC Press.

Kumar R. \& Raj H. (2018). Threat and Mitigation of Ground Water Contamination in India, Acta Scientific Nutritional Health, 2(8), 29-31.
Masters, G.M. (1998). Introduction to Environmental Engineering and Science. New Jersey: Prentice Hall.

Reza, R. \& Singh, G. (2010). Assessment of Groundwater Quality Status by using Water Quality Index Method in Orissa, India. World Applied Sciences Journal, 9(12), 1392-1397.

Richard, L.A. (1954). Diagnosis and Improvement of Saline and Alkalis Soils. Agric. Handbook 60. Washington DC: US Department of Agriculture.

Tay, C., \& Kortatsi, B. (2008). Groundwater quality studies: a case study of the Densu Basin, Ghana. West African Journal of Applied Ecology, 12(1). Retrieved from: https://www.ajol.info/index.php/wajae/article/view/45760/29237

Todd, D., Leaden, F.V. \& Trosise, F.L. (1990). The Water Encyclopedia, $2^{\text {nd }}$ edn. New York: John Wiley and Sons.

US-SL (1954). Diagnosis and improvement of saline and alkali soils. Handbook 60. US Salinity Laboratory. Washington DC: US Department of Agriculture.

WHO (2003). Guideline for Drinking-Water Quality. 3rd edn. Geneva: World Health Organization.

\section{Summary}

Groundwater assessment at east side of Mosul City during 2014-2017. This study assesses groundwater quality GWQ at the east side of Mosul city for different purposes during 2014-2017. Eighteen shallow wells distributed in residential areas are selected and assessed by analyzing their physical, chemical and biological properties. This study reviews the textures of sub-layers by using groundwater modelling system (GMS) to show the probability of infiltration of nearby wastewater and gray water. This study analyzes epidemiological data about diarrhea cases that were increased during that period and calculating the relative, attributed and odd risk. There are three types of assessment are conducted including ranking assessment, weighted assessment and geographical information systems (GIS) assessment. A final 
map is created to show the most suitable area for live stock and irrigation purposes. The results show that the studied groundwater samples are unsuitable for drinking. High damage can happen for crops with sensitivity for salinity. Most wells are acceptable for live stock purpose.

\section{Authors' address:}

Ali Zain Al-Aabedeen Al-Ozeer, Mohammed Fakhraldeen Ahmed Mosul University

College of Environmental Sciences and Technology Department of Environmental Technology

Mosul, Iraq

e-mail: Ali.zen989@gmail.com

mfakher1962@gmail.com 